\title{
Correction to: On $\mathbb{Z}_{2} \mathbb{Z}_{4}[\xi]$-skew cyclic codes
}

\section{Fatmanur Gursoy ${ }^{1} \cdot$ Ismail Aydogdu ${ }^{2}$}

Published online: 12 July 2021

(c) Korean Society for Informatics and Computational Applied Mathematics 2021

\section{Correction to: Journal of Applied Mathematics and Computing https://doi.org/10.1007/s12190-021-01580-3}

This correction is published as vendor overlooked several corrections during proofing.

Affiliations of author Ismail Aydogdu should read as Department of Mathematics, Yildiz Technical University, Istanbul, Turkey.

Original article has now been corrected.

Publisher's Note Springer Nature remains neutral with regard to jurisdictional claims in published maps and institutional affiliations.

The original article can be found online at https://doi.org/10.1007/s12190-021-01580-3.

Ismail Aydogdu

iaydogdu@yildiz.edu.tr

Fatmanur Gursoy

fnurgursoy@hotmail.com

1 Istanbul, Turkey

2 Department of Mathematics, Yildiz Technical University, Istanbul, Turkey 